\title{
THE HERSCHEL OBELISK, CLASSICS, AND EGYPTOMANIA AT THE CAPE
}

\author{
J L Hilton (University of KwaZulu-Natal, Durban)
}

Immediately prior to his departure from Cape Town to England in 1838, Sir John Herschel sold the estate, 'Feldhausen', ${ }^{1}$ on which he had erected his telescope and had conducted his astronomical observations, to Mr. R. J. Jones, an auctioneer. The property was sold with a servitude: a circular patch of ground 63 feet in diameter bounded by newly planted fir trees was to be kept in Sir John's possession in perpetuity. ${ }^{2}$ This area marked the spot on which the telescope had actually stood. At the centre of the circle Herschel placed a small cylindrical column of granite engraved 'I. H. 1838' representing his initials in Latin (for Ioannes Herschelius) and the year in which he had completed his work and was leaving the colony. ${ }^{3}$ Subsequently, the members of the South African Literary and Scientific Institution, of which Herschel had been President, ${ }^{4}$ decided to commemorate his scientific achievements and his contributions to education in the Cape. At first they had the idea of devising a series of six gold medallions inscribed with the details of his scientific achievements. ${ }^{5}$ These had been paid for by a voluntary subscription and were designed by Herschel's assistant, Charles Piazzi Smyth, whose father Rear-Admiral William Henry Smyth had recently (1834) published a catalogue of Roman Imperial medals. ${ }^{6}$ However, more had been collected than was expended and so the members decided to widen the scope of the exercise and to erect a more suitable memorial on the ground on which the telescope had stood. A meeting of the subscribers chaired by the Governor, Sir George Napier, was held in November 1838 to decide on the form the memorial should take. The resolutions taken at the gathering stated that it was to be 'a permanent memorial' and, although no further information about its exact architectural form was given is given in the resolutions, it must be assumed from subsequent references that it was to be an obelisk. ${ }^{7}$ The committee requested Professors Forbes and Henderson (who had been the second Royal Astronomer at the Cape) to arrange for stone-cutters to make a yellow-granite obelisk from a granite slab taken from a quarry near Edinburgh. ${ }^{8}$

\footnotetext{
Herschel gave this German name to the estate. It was known in English as 'The Grove'.

The exact servitude is cited by Warner 1978: 57.

For these details see McIntyre 1954: 90. The site as Herschel left it can be seen in a drawing made by Charles Piazzi Smyth, which is reproduced by Warner 1978: 57, fig. 1.

See Barnard 1954: 10-11, 13.

The English inscriptions on the medallions are reproduced in Warner 1978: 64, fig. 2. Smyth 1834.

The resolutions are quoted by McIntyre 1954: 89. Warner 1978: 57-59 quotes a series of letters from Maclear to Herschel. One dated 21 September 1838 stated 'that it is in contemplation to erect a massive granite monument over your Pillar.' In November 24, 1838 this had become a 'column'. By March 8, 1841 it was an 'obelisk'.

8 The obelisk soon lost its colour and already appeared dark and unsightly in 1852, see Warner 1978: 68.
} 
After considerable controversy about the final location of the monument (some wanted it to be erected on the Parade in Cape Town) it was erected on the Feldhausen estate (previously named 'The Grove') in 1841 (although the final piece was only added in February 1842). It is now a national monument (and has been since 1934) and still stands in the grounds of The Grove Primary School in Claremont.

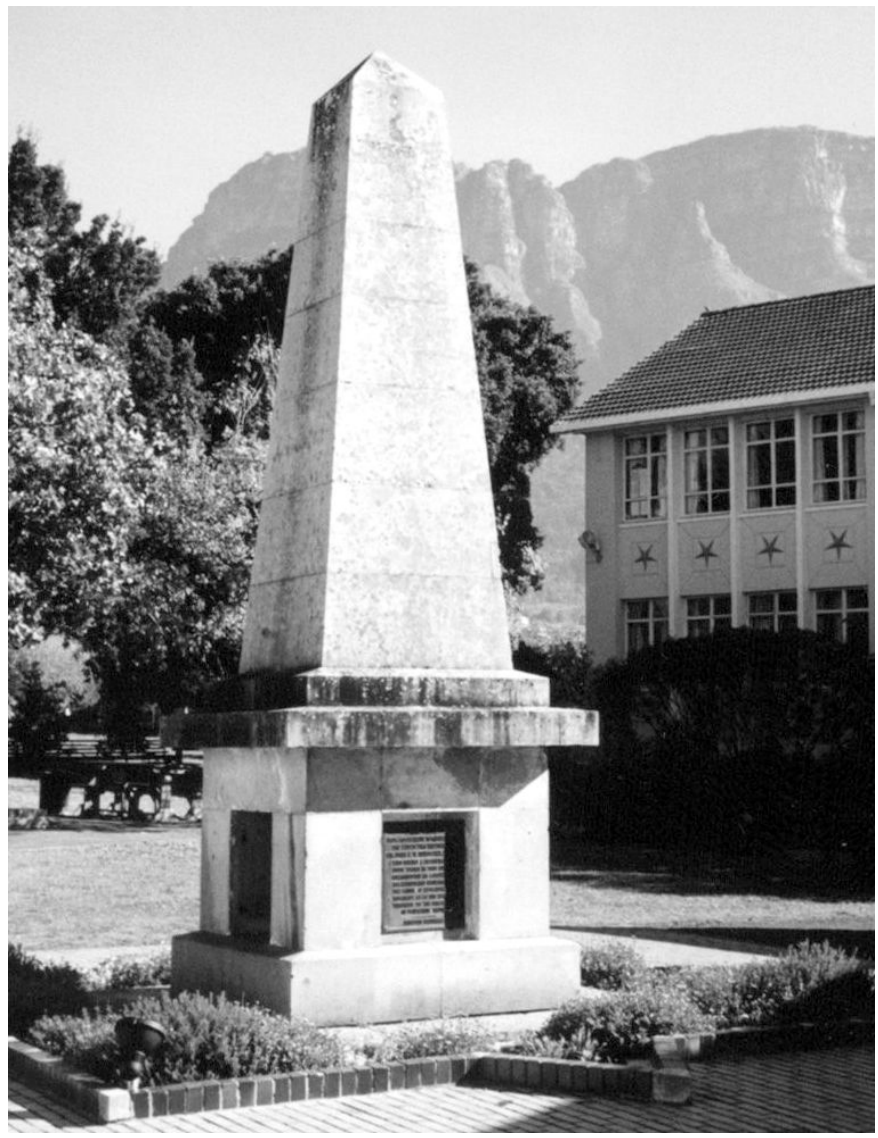

Fig. 1 The Herschel obelisk and inscription

The obelisk (Fig. 1) consists of seven square tapering courses of granite topped with a pyramidal cap. It rests on a double-layered plinth on top of a square base. One side of the base of the monument is hollow and contained a 'time capsule', containing the six medallions designed by Smyth, a map of the colony, Maclear's triangulation of Cape Town, a six-inch standard scale, engravings of the nebulae and comets observed by Herschel, a statistical account of the Cape settlement, and coins of the British mint. ${ }^{9}$ These items were put into a bottle encased in a block of teak, which was then sealed with pitch. On two other sides of the base there are inscriptions in English and in

$9 \quad$ A similar 'time capsule' was later deposited within the London obelisk (Iversen 1968: 2.135) and inscriptions were similarly attached to the base (ibid. 2.136). 
Latin. ${ }^{10}$ These were only fixed to the obelisk much later and initially caused great difficulty. In a letter to Maclear on 20 February 1842, Smyth writes that a member of the committee, Colonel Lewis:

'proposed to make 3 inscriptions and to put 1 on each of the 3 blind faces of the Obelisk ... he then forked forth from his pocket 3 inscriptions which he had prepared, which seemed appropriate enough, \& from which the mention of public schools had been omitted. The inscription which came out from England he thought too long to put into one of the faces without making the letter improperly small . . . Two meetings of the Committee have already been held for the purpose of deciding on the Inscriptions, but they have separated after a deal of unfruitful discussion. A third will be held on March 2nd to allow of your being present., ${ }^{11}$

The Latin inscription was composed by Herschel, or possibly by Lady Herschel. Maclear writes: 'Lady Herschel sent out two inscriptions, either of which might be used', without specifying the language in which the inscriptions were written.

SPECULUM SESQUIPEDALE
IN ANGLIÂ
PROPRIIS FACTUM MANIBUS
HOC SITU POSUIT
JOHANNES F. W. HERSCHEL
ET QUATUOR PER ANNOS
QUOAD LONGISSIME MICANT
ORBES NEBULAEQUE CELESTES
SEDES EORUM ET SPECIES
PERITISSIME NOTAVIT.
SIC OPUS ILLUD INSIGNE
A PATRE CLARO ET A SE IPSO
BOREALI SUB CELO INCEPTUM
EODEM QUASI OCULO
IN AFRICA
FILIUS PIE PERFECIT.

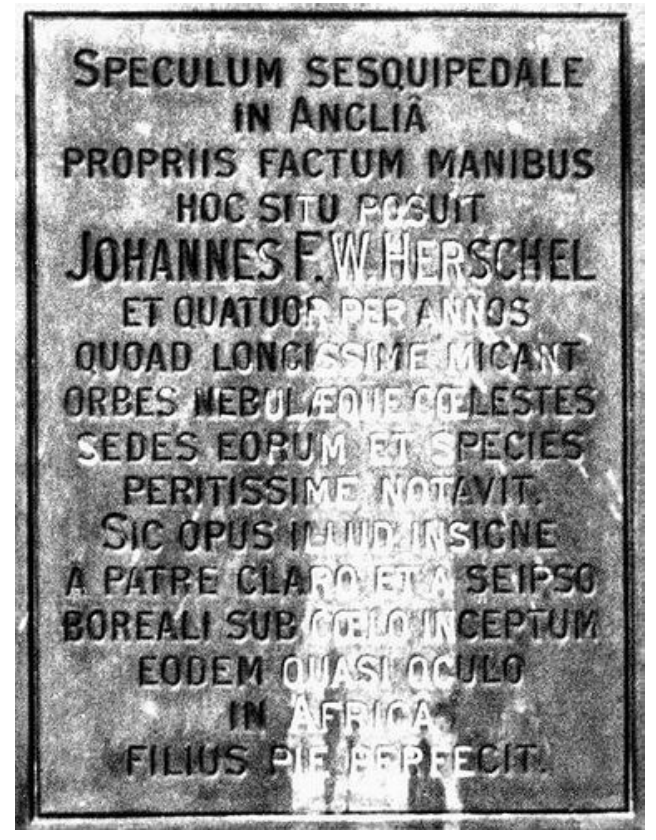

Fig. 2 The Latin inscription

Copies of these inscriptions were found in the Herschel family papers and John Maclear (the son of Thomas Maclear) and Herschel's sons decided which to use at a

\footnotetext{
10 The English inscription reads: 'During the residence of four years in this colony [Sir John Herschel] contributed as largely by his benevolent exertions to the cause of education and humanity as by his eminent talents to the discovery of scientific truth.'

11 Quoted by Warner 1978: 91.
} 
meeting in Slough, England, on 9 November 1903. This was cut onto a bronze plate and shipped to Cape Town in February 1904.

Warner notes that 'the Herschel family provided a smaller inscription plate (in Latin) in 1905. These, and an unsightly protective iron fence around the obelisk, were installed by the Claremont Municipality'. ${ }^{12}$ The Latin inscription (Fig. 2), which appears to have been attacked with acid and needs restoration, may be transcribed as follows:

'At this site John F. W. Herschel placed a very large mirror [reflecting telescope] that he made with his own hands in England and for four years he expertly observed the furthest extent to which stars and nebulae in the sky shine, their positions, and their types. Thus the son dutifully completed in Africa as if by the same eye the outstanding work begun by his famous father and by himself in the northern hemisphere. ${ }^{, 13}$

\section{Herschel and Classical literature}

The Latin inscription reflects Herschel's training in Latin. But he clearly also loved Classical literature. Isabella Herschel's catalogue of the books of the Herschel Library (belonging to William and later John Herschel) at Sir John's residence at Collingwood in Kent and now in the Toronto University Library reveals a long list of Classical authors, which 'served him as sources for apposite quotations in Latin and Greek’ (Ross 2001: xi).

Herschel gave considerable thought to the value of the Classics in the context of South Africa at the beginning of the nineteenth century. In response to a request from his brother-in-law, Dr. Duncan Stewart, for an outline of a course of study that Herschel would regard as 'standard and preeminent authorities in a great variety of departments' (Herschel 1834: 1), he expressed the pessimistic (and frankly racist) view that European religion and thought would not be able to influence African culture. He argued that the Egyptians had built trade routes into Africa but had failed to 'leaven the negro mass' (1834: 3).

Similarly, he pointed out that Hellenistic culture had not been able 'to make a permanent mark on the natives of Africa' (ibid.) and had instead been overpowered by Egyptian ways. Nevertheless, he thought that South Africa was similar to North Africa with respect to physical geography and human society: 'Roman Africa was a country like our own, where several languages subsisted side by side’ (ibid. p. 4). He was thinking here of the coexistence of Latin and Greek with the Berber language as exemplified by Apuleius, whom he labelled 'the author of a diverting, though hardly edifying romance'.

He pointed out the remarkable achievement of the African church fathers in the development of Christianity, the agricultural wealth of the province, and the later growth of schools of learning under Arabic influence, but concluded that:

\footnotetext{
12 Information about these incriptions is taken from Warner 1978: 69.

13 The translation is my own. The inscription has not been previously translated, to my knowledge.
} 
' . . . this culture perished utterly - to know the reason would be a valuable lesson to us who have succeeded to the task of the Roman at this end of the continent. Africa emerged, the religion, the laws, and the letters of Europe fell back baffled from her soil. . . To try to create in South Africa a mere slavish imitation of those great foundations of Europe which we admire seems to be impossible’. (Herschel 1834: 4).

Herschel therefore rejected the uncritical implementation of a European Classical education in South Africa. However, he did not denounce the study of the Classics entirely, and vigorously opposed those who would reject the subject in favour of more pragmatic studies. Instead he noted that 'the apostle of sweetness and light, Mr. Arnold, is a strenuous advocate of what has become known as 'the humanities' (ibid., p. 5). He suggested that a middle path would be most sensible, noting that Latin had been restored to a place of honour in the school curriculum of the United States after initially falling away. In this Herschel reveals his instinct for compromise, which was evident also in his political view of the value of the Roman equestrian class, who 'mitigated the otherwise intolerable step between Patrician and Plebeian' (ibid., p. 11). His educational ideas with regard to the Classics are still pertinent today and are perhaps even more urgent than they were in his own time. He identified three areas of particular importance: the Egyptians, Hellenism, and the Roman province of North Africa.

Herschel's reading at the Cape included Edward Bulwer Lytton's Last Days of Pompeii, which had just been published (in 1834). ${ }^{14}$ He translated Homer's Iliad into 'English accentuated hexameters' in order to capture the effect of Greek hexameter verse in the accentual rhythms of English. ${ }^{15}$ He rejected the possibility of using the 'decasyllable Iambic of Milton and Pope, varied only by the Alexandrine, as in the Spenserian stanza', after rendering the first ten lines of the Iliad in this way, on the grounds that this metre is better suited to satire, not epic (1866: viii). Herschel began his translation, which he dedicated to the memory of the late Master of Trinity College, Cambridge, in October 1861, 'on the occasion of reading an article in the Times of the 28th of that month on Translations, while in ignorance that any entire book of Homer had ever before been placed before the English public in its original metre' (p. xi-xii). ${ }^{16}$ He aimed to avoid the repetition of epithets ('which is tiresome') and does not present the Greek names of the divinities (instead a Latin name is used). 'Expletory' words to suit Homer's tautologous style are indicated in italics. An example of the opening lines of Iliad 1 from Herschel's translation is given below:

Sing, celestial Muse! the destroying wrath of Achilles, Peleus' son: which myriad mischiefs heaped on the Grecians, Many a valiant hero's soul dismissing to Hades;

Flinging their corses abroad for a prey to dogs and to vultures, And to each bird of the air. Thus Jove's high will was accomplished.

Evans et al. 1969:137; Ross 2001: xi.

Herschel 1866.

Herschel also had a love for German poetry and translated Schiller's poem 'Spaziergang' in 1833. See Herschel 1833. 
Ev'n from that fateful hour when opposed in angry contention

Stood forth Atreides, King of men, and godlike Achilles.

Say, then! which of the Gods involved these two in their conflict?

Jove's and Leto's Son! For he, with the leader offended

Sent on his army a plague, and his people were perishing round him:

For that Atreides his sacred Priest had rudely dishonoured;

Chryses, who suppliant came to the swift-sailing ships of the Grecians

Eager to rescue his daughter, and proff'ring unlimited ransom.

While he was at the Cape, Herschel also played an active role in raising the standard of education in the colony. ${ }^{17}$ Although he was given a traditional, Classical education, Herschel was a liberal (Whig), ${ }^{18}$ who followed thinkers such as Francis Bacon (especially the Novum Organum) and John Locke in advocating a broader and more general education that would lay stress on the ancient languages, but demand at least one modern language in addition to the mother tongue in the curriculum. He was particularly interested in science and mathematics. ${ }^{19}$ Herschel expressed these views in his speech at a prize-giving ceremony at the South African College (SACS) in 1836 or 1837 (In Herschel's handwriting this is labelled: oratio habita in collegio Africano-merid' (= meridiano). ${ }^{20}$ Here he states that it is not enough to take one's place in society as a gentleman, and that the boys of the early nineteenth century would grow up in a scientific age:

'Sir, If I were to characterise the present age of the world by any single word, it would be by that of a Scientific age - an age of thought carried out into action, an age of the application of the inductive philosophy to all the purposes of life and to the improvement of the human condition upon earth.'

Nevertheless, despite this emphasis on science and mathematics, Classics was retained as an important element in the education of young people at the Cape. Herschel provided an examination paper to test those applying for a teaching post, in which, besides questions on Euclid Book 1 (which counted as 'abstract science'), Political Science, German, History, and Geography, applicants were asked to give 'a very close and literal translation into English’ of Cicero Cat 1.9:

O di immortales! ubinam gentium sumus? quam rem publicam habemus? in qua urbe vivimus? Hic, hic sunt in nostro numero, patres conscripti, in hoc orbis terrae sanctissimo gravissimoque consilio, qui de nostro omnium interitu, qui de huius urbis atque adeo de orbis terrarum exitio cogitent. Hos ego video

17 See Ferguson and Immelman 1961. For the teaching of Classics in the early days of the Cape Colony see Smuts 1960: 3: 7-31, esp. p. 11. Smuts discusses Herschel's educational ideas and teaching appointments on pp. 12-14. Inter alia Smuts notes that Herschel recommends that 'a small vocabulary of Greek roots, which are commonly found in art and science, should be learned' (p. 12). This anticipates by almost two centuries courses such as Words and Ideas. Herschel was also a liberal in politics, he supported the abolition of slavery at the Cape and the missionary Philip who opposed Benjamin D’Urban’s annexation of Xhosa land.

19 Ferguson and Immelman 1961:5-6.

20 This speech is reproduced in Ferguson and Immelman 1961:52-58. 
consul et de re publica sententiam rogo, et quos ferro trucidari oportebat, eos nondum voce volnero! Fuisti igitur apud Laecam illa nocte, Catilina, distribuisti partis Italiae, statuisti quo quemque proficisci placeret, delegisti quos Romae relinqueres, quos tecum educeres, discripsisti urbis partis ad incendia, confirmasti te ipsum iam esse exiturum, dixisti paulum tibi esse etiam nunc morae, quod ego viverem. Reperti sunt duo equites Romani qui te ista cura liberarent et se illa ipsa nocte paulo ante lucem me in meo lecto interfecturos esse pollicerentur.

A 'free translation into Latin' of a paragraph from a recent issue of the The Spectator was also required. The Greek paper was to consist of a question in which candidates were to copy out Sophocles Oedipus Tyrannus (1-6) 'without the contractions', and 'to mark their scanning and the quantities of the syllables'. A second question required the writing down 'from memory some passage in a Greek poet or prose writer - or some verses in the Greek testament'. ${ }^{21}$

\section{Egyptology at the Cape}

The choice of an obelisk as the architectural form of the Herschel monument also points to a significant interest in Egyptology at the Cape in the early nineteenth century, especially among the scientific community. At the time, Egyptomania was rife in Europe and the United States. ${ }^{22}$ Egypt had long been the source of fascination for English astronomers in particular. John Greaves, the Professor of astronomy at the Oxford, initiated the enthusiastic interest in the pyramids of Egypt in the seventeenth century. ${ }^{23}$ The learned academic, who had an unusual knowledge of Arabic and an interest in the Orient, ${ }^{24}$ visited Egypt in $1637 / 8$ as part of a tour of the Middle East to locate and purchase Arabic translations of the Greek mathematical works.

He was also interested in establishing an accurate standard for measurements for which he turned to the ancient system of weights and measures. In doing this he was following the example of Isaac Newton. He took astronomical instruments with him on this tour and took observations of the stars in Egypt. To relax he went to investigate the Great Pyramid of Cheops taking with him his measuring rods ('being

$21 \quad$ Ferguson and Immelman 1961:68-70.

22 Curl 1994 provides an excellent account of Egyptomania, from Roman times until the twentieth century that focuses on the use of Egyptian forms and images in the art and architecture of Europe. See also Humbert, Pantazzi, and Ziegler 1994. Egyptian motifs were widespread in the architecture of the United States, as shown by Carrot 1978. For a more critical account of Western appropriation of Ancient Egypt, see Jeffreys 2003, part of a revisionist examination of Egyptology in eight volumes under the general title Encounters with Ancient Egypt. Fekri Hassan's chapter, 'Imperialist Appropriations of Egyptian Obelisks' (pp. 19-68) discusses the transportation of Egyptian obelists to the capitals of Europe and the United States 'in order to canonize their world hegemony' (p. 19). The Herschel obelisk is, of course, not an instance of cultural appropriation but rather of cultural acknowledgement.

23 See Greaves 1646; 1706. For Newton's interest in ancient units of measurement, see Brück and Brück 1988:98.

24 For European interest in the Orient and especially Egypt, see Saïd 1978, although he does not discuss Greaves and the Great Pyramid Debate. 
spent with labour and watching, I went twice to divert myself to Memphis [Cairo]'). ${ }^{25}$ He explains his purpose as follows:

'Then I went to the pyramids, and having fit instruments for that purpose, took their exact dimensions, observing there many things, as I curiously view'd them, which have not been delivered in writing either by the ancient or modern authors. They are reckoned by the ancients among the wonders of the world, but not yet described as they ought to be by any one that I know of. I carefully took the dimensions of the inner chamber, and some more private places, which time has not yet, nor, if I mistake not, ever will destroy, with English measures, and that so exactly, that I believe there is not one part over or under of 20000 , into which twenty foot are divided by cross, or rather diagonal lines. Which I was the more exact in, to the end that the measures of all nations that now are, or formerly were, may be transmitted to posterity from some lasting monument, by comparing them with these. Had this been formerly done by mathematicians, choosing for the purpose some proper places not exposed to the injury of time, we should not at present be so uncertain in the search after the measures of the ancients. ${ }^{26}$

He later published an accurate description of all three of the pyramids at Giza in his Pyramidographia (1646) together with a discussion of the 'authors' of the pyramids and the purpose of these structures, which he decided was funereal (Greaves 1646: 43-66). In doing this he was struck by the fact that the pyramid measures corresponded closely with their English equivalents. ${ }^{27}$

Approximately three decades later in 1670, the French priest Gabriel Mouton proposed to use divisions of the arc of the circumference of the earth as a unit of measurement (the metre), supplemented by the swing-length of a pendulum (about 25 centimetres). This system after some modification and expansion into units of volume became the official system in France in 1799 and compulsory in 1840. Reformist British scientists in the nineteenth century had also put forward similar ideas of a uniform system of weights and measures, but most nations have followed the French model, and the Anglo-Saxon nation states (the United Kingdom and the United

25 Quotation from a letter of Greaves to Claudius Hardy prefaced to a reproduction of Greaves' Pyramidographia 1646 in a collection of voyages and travels printed in six volumes (London 1732: 2.826-868).

26 Loc. cit. in previous note. Greaves also wrote a treatise on the Roman foot and denarius (Greaves 1732).

27 See Greaves $1745^{2}$ : 68-69, and the preface: 'For 'tis scarce to be doubted that the Ancients, who thus carefully preserved here [in the Great Pyramid] their primitive Measures with so much Accuracy, would be less careful to leave behind them some Monuments [the Pyramids] of what other Arts their Wisdom and long Experience had found out for the Benefit of Mankind ... [T]he true origin of our English Measures . . . and their great Antiquity here found, by their near agreement with these most antient standards, was a prevailing Motive with me not to conceal these Things.' 
States) are now virtually the only ones in the world who have yet to commit themselves entirely to it. ${ }^{28}$

Interest in Egypt and its monuments had also been excited in Herschel's day by the famous invasion of Egypt by the Emperor of France, Napoleon I, between the years 1789 and 1801. Napoleon was accompanied by about fifty savants, such as Baron Dominique Vivant Denon, who was responsible for many of the many drawings. These scholars accumulated vast amounts of information about the country that were subsequently published in the twenty-three volume (ten of text, thirteen of illustrations) Description de l'Egypte (1809-1828) under the name of Napoleon but coordinated by Joseph Fourier. ${ }^{29}$ One of the principal tasks of these scholars was to measure the Great Pyramid and one of the illustrations in the Description shows scholars with plumb-lines clambering over the Sphinx.

Some English intellectuals took up Greaves' arguments concerning the close approximation of the English and Egyptian units of measurement. Chief among these was John Taylor who published his book The great pyramid: Why was it built? And who built it? in 1859, after working on it for two or three decades. Taylor was a devout Christian and believed that the Pyramid measures were a divine gift to humankind. He believed that the pyramids were not intended to house the bodies of the pharaohs (pointing to the absence of mummies - but these had long since been looted, of course), rather he thought they were monuments intended to preserve and record the ancient units of measurement such as the sacred cubit and the pyramid inch for posterity.

Taylor noted a number of extraordinary near coincidences derived from the measurements of the Great Pyramid. The first was that the height of the pyramid was 486 English feet, which when multiplied by 270,000 resulted in a figure of $131,220,000$ feet, which, in Taylor's eyes, was approximately equivalent to the actual circumference of the earth in feet $(130,908,000)$. Taylor was prepared to tolerate a fair degree of inexactitude however; he also claimed that the circumference of the earth $(130,908,000)$ multiplied by the length of the base of the pyramid is approximately 100 billion (one hundred thousand million). The actual figure is $100,013,712,000$. The second was that the pyramid provided a solution to the mathematical problem of 'squaring the circle', since the height of the Great Pyramid is equal to the radius of a circle whose circumference is equal in length to the sum of the four sides of its square base. The third was that the diameter of the earth could be expressed in approximately 500 million English inches. The fourth was that the logarithm of the height of the pyramid, when added to the logarithm of half the height of the pyramid, is $\sin 26^{\circ} 19^{\prime}$ and that this was the angle of incline of the entrance to the pyramid from which the pole star could have been observed in $2100 \mathrm{BC}$, when the pyramid was constructed. The information on which the last deduction was based was

28 This debate is still waged through the pages of the British press and each side has an association to champion its cause: The United Kingdom Metric Association vs. The British Weights and Measures Association. South Africa is a model of metrification. South Africa adopted the metric system in 1961, the same year in which it left the British Commonwealth.

29 This massive publishing venture can be consulted most accessibly in the coffee-table edition by Serino 2003. 
provided by Herschel's massively popular Outlines of Astronomy (1849) of which Taylor had been co-publisher. Herschel had identified Alpha Draconis as the exact star involved in response to a request by another measurer of the Great Pyramid (of which there were many), Howard Vyse (1840). ${ }^{30}$

The second edition of Taylor's book (in 1864) reprinted two letters by Sir John Herschel in support of his cause (Taylor 1864: 39-44), but although Herschel was sympathetic (he resigned from the Standards Commission when it came down in favour of the metric system and wrote a critical article on the metre) ${ }^{31}$ he was nevertheless extremely sceptical of Taylor's theory and tried to preserve his scientific credibility by staying out of the controversy as far as possible. ${ }^{32}$ He wrote:

'I ought in fairness to mention, that my attention was drawn in the first instance to this rapprochement by the statement, over and over again repeated in Mr. Taylor's recent work. entitled, The Great Pyramid: Why was it Built etc. (Longman 1859, pp. 35, 36, 37, 87, 280, 298 etc.) that the diameter of the earth in the latitude of the pyramid is 41, 666, 667 English feet, or 500,000,000 of English inches, which it is not.'

In order to sustain the argument for the English units of measurement against the sceptics, the exact length and height of the Great Pyramid was essential. There were other imponderables too, such as that the earth is not exactly spherical and so its circumference at the equator is not the same as its circumference around the poles. Further inexactitudes had been introduced by the fact that earlier scientists had not taken the exterior casing of the pyramid into account and had not used the corner stones of the structure as the point from which to measure. There was still much to do therefore.

Taylor died in 1864 but his struggle in the 'Battle of the Measures' was taken up by Charles Piazzi Smyth, who had been Herschel's assistant at the Cape (18351845) and who had gone on to become the Astronomer Royal in Edinburgh. It was in all probability Smyth who initiated the acquisition of granite from Edinburgh for the Herschel obelisk, since Smyth's father had contacts in that city, with whose help his son was appointed to the position of Astronomer Royal. Smyth, like Taylor, was an intensely religious man, ${ }^{33}$ who saw his life work to lie in defending Taylor's thesis. In this, he was but part of an entire movement known as the British-Israelite movement, who believed that the Anglo-Saxon races were descended from the lost tribes of Israel. ${ }^{34}$

Masonic influence may also have been involved. In a letter to Herschel dated 28 March 1842 Maclear, in referring to the campaign to locate the monument on the

30 Another writer on the movement was Charles Casey (1877) who quotes Isaiah 19:19-25 on the frontispiece to the book. Casey's breathless description of his experiences in Egypt anticipates today's journalistic travel writing.

See Brück and Brück 1988: 100. For his essay on the metre, see Herschel 1863.

See Brück and Brück 1988: 124 on Piazzi Smyth’s attempt to involve Herschel in the struggle.

Brück and Brück 1988: 107.

Brück and Brück 1988: 133. 
Parade in Cape Town, suggests the influence of a Masonic Temple in the planning of the obelisk:

'A week after an opposition subscription list was set on foot, and the librarian of the public library [Alexander Johnstone Jardine], who was of the party [to move the obelisk to the Parade] employed his graceful persuasive smiles in seducing the Temple. ${ }^{, 35}$

Weisse (1880) identified masonic symbols in the New York obelisk and observed (p. 3) that: 'Anyone who will take the trouble to read this epitome and consider its illustrations [including those of the obelisk], will realize that secret societies like Freemasonry existed in remote antiquity, and were the prerogative of kings, hierophants, and magnates.'

Smyth published numerous books on the Great Pyramid and its measurements: Life and Work at the Great Pyramid in Three Volumes (1867); On the Antiquity of Intellectual Man (1868); A Poor Man's Photography at the Great Pyramid (1870); The Great Pyramid and the Royal Pyramid (1874); and Our Inheritance in the Great Pyramid (1874). The last book has gone through numerous editions and is still available in print. Smyth had received a thorough education in the Classics, ${ }^{36}$ but was also a pioneer in a number of branches of knowledge, following Herschel in investigating astronomy and photography, but making Egyptology his own special area of interest. Piazzi Smyth had inherited his love of archaeology from his father, Rear-Admiral W. H. Smyth, who had been involved in the Napoleonic Wars in the Mediterranean and in the campaign served under Horatio Nelson in his victory over the French Emperor in the Battle of the Nile. Admiral Smyth negotiated with 'Mehmet Ali' (= Mohammed Ali Pasha below), 'the pharaoh of the 19th century' about the possible transportation of an obelisk, now known as 'Cleopatra's Needle ${ }^{37}$ from Alexandria to London (Fig. 3). ${ }^{38}$ Wilson (1878: vii) notes that: 'in 1822 a distinguished naval officer Admiral W. H. Smyth, drew up a statement of the plans by which the transport of the obelisk might be accomplished and Mehmet Ali offered to assist by building a pier for the purpose.' The Admiral's son, Piazzi Smyth, later made use of the services of John Dixon, the engineer who was responsible for the design of the ill-fated ship which was to transport the obelisk to London, ${ }^{39}$ to take the measurements of the pyramid. W. H. Smyth even name one of his daughters Rozetta after the stone which formed the key to Champollion's decipherment of hieroglyphics in 1822.

35 For the influence of the Masonic movement, which widely uses Egyptian symbols, in the pyramid debate, see Evans 1895, Rowbottom 1880; Weisse 1880. For a recent account of Freemasonry and Imperialism, see Harland-Jacobs 2007.

36 Brück and Brück 1988: 5.

37 The two obelisks in Alexandria had been named 'Cleopatra's Needles' by Abd' al Latif in the 12th century.

$38 \quad$ Brück and Brück 1988: 97

39 This cylindrical steel ship capsized in the Bay of Biscay while carrying the obelisk to London. 


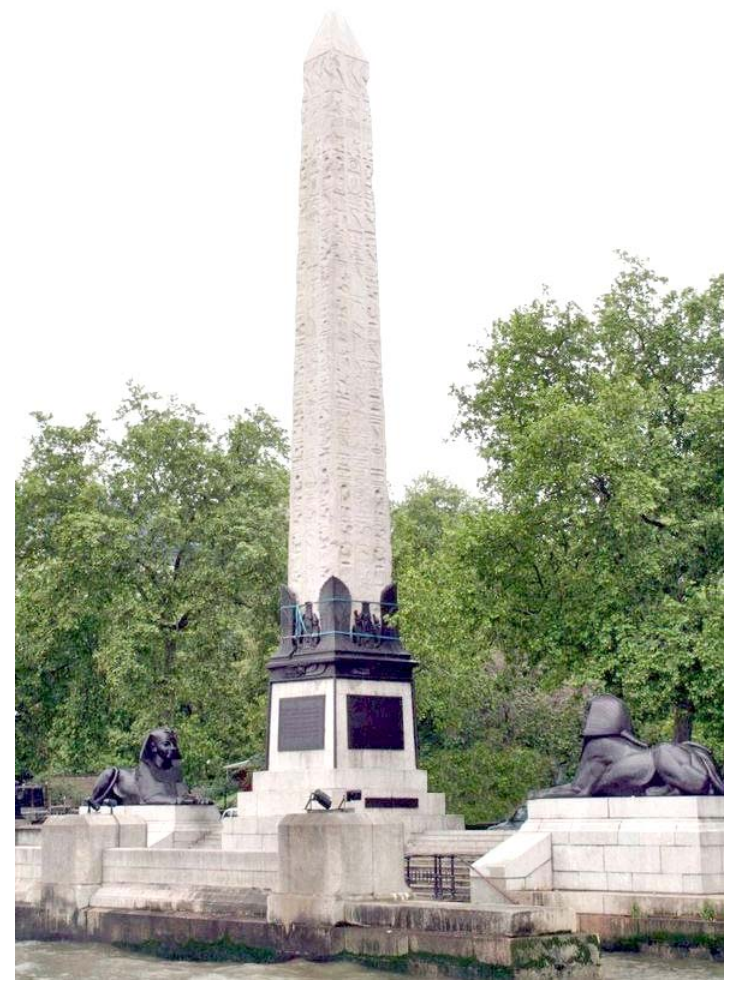

Fig. 3 The London obelisk

The London obelisk is accompanied by two sphinxes on either side of it (Fig. 4). These were modelled on smaller stone sphinxes at Alnwick Castle, Northumberland and were designed by George Vulliamy and cast by Young \& Company. ${ }^{40}$

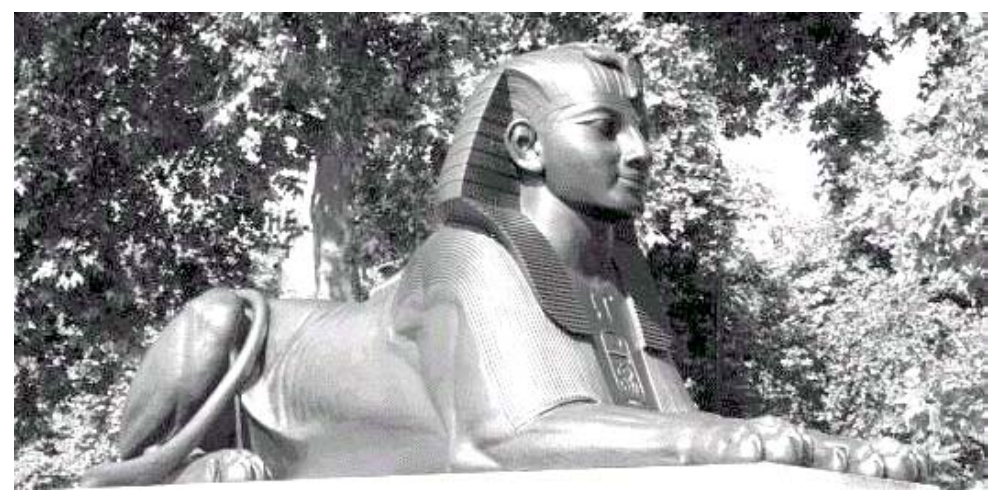

Fig. 4 One of the sphinxes next to the London obelisk 
The story of the two obelisks which had lain in Alexandria since Augustus had moved them there from Heliopolis in 23 BC was one which fascinated English readers in the early nineteenth century. ${ }^{41}$ One was eventually moved to London in $1878^{42}$ and the other landed up finally in New York in $1881 .^{43}$ The process was extremely expensive and took many years to complete. The idea was first proposed in 1801 when the Needle was given to Mohammed Ali Pasha after the English victory over the French. An inscription on a brass plate commemorating the victory was enclosed in the pedestal of the obelisk. In 1820 the question was again raised by Samuel Briggs, the British consul in Alexandria, who wrote to Sir Benjamin Bloomfield, one of the ministers of George IV, proposing to bring the needle as gift to king. In 1831 Muhammad Ali again presented the needle to the British King and proposed to defray all expenses incurred in removing it from the place where it lay. In 1849 the British government declared on April 15 that they intended to bring the obelisk to London in response to questions in Parliament by Joseph Hume. Various other initiatives were made subsequently before it was finally brought to England in 1877 through the efforts General James Alexander, who made use of Piazzi Smyth's acquaintance, the engineer John Dixon, and the financial support of Erasmus Wilson. ${ }^{44}$ It is probable therefore that the issue would have been much discussed in Herschel's day. Moreover, great political significance was attached to the obelisks. As the American writer Moldenke (1891: viii) puts it:

'Here in the western land the obsequious adoration of one man is no more. Here the people are not under the lash and miserable; they are, with all their cares and labors, a happy and contented people. The realm is not as in those former days, the result of a despot's triumphant march, but a grand, harmonious union of friends. On such a picture our obelisk looks down from its lofty pedestal. Had it a tongue, it could tell us many a tale of the past, when Thothmes III erected it with pomp and festivities, when Ramses II engraved his name upon it, and the law-giver Moses, the Israelite, played and studied in its view, how it escaped the fury of the demoniac ravager Cambyses, was transported by the Romans to Alexandria, escaped Mohammedan fanaticism, and was at last conveyed as a precious prize from its sunny home to our fitful climate. It seems oddly out of place here, and its coat of paraffine will not protect it wholly from bleak winds and rain, and winter's ice and snow. It has lived its longest time on earth and at the advanced age of thirty-four centuries it must decline, until it will totter and fall. Then having so long symbolised the

41 These obelisks had been quarried in Syene and were erected in Heliopolis by Thothmes III in the eighteenth dynasty.

42 On the transportation of Cleopatra's Needle to London, see Wilson 1877: passim and Wallis Budge 1926: 51-78. There is also a more recent, and copiously illustrated account in Iversen 1968: 2.90-147, which reveals the extent to which the issue of the Needle became a media event in nineteenth-century English society. Even Charles Dickens was drawn into the debate (Iversen 1968: 2.113, n. 3).

43 An account of the transportation of the New York obelisk is given in Gorringe 1882; Moldenke 1891. See now also Iversen 1968 and many others.

44 Information taken from Budge 1926: 51-64. For the Masonic relationship between Dixon and Wilson, see Iversen 1968:2.120. 
'Rising Sun' in all its beauty, and having greeted its glorious advent with every dawn and break of day, the 'Setting Sun' will shroud it for the last time in its light, but the new sun of morning will seek its old friend in vain. It will fade away, but its memory will last much longer than inscriptions on stone which must perish sooner or later. Let us, however, the children of a new era, learn from it the greatness of its authors!'

Similarly, the London Needle symbolised that this city, like the others to which Egyptian obelisks were taken, such as Rome, Constantinople, and Paris, were centres of imperial power and cultural pre-eminence. Rome had set the example with fourteen obelisks. ${ }^{45}$

From what has been said above, it is clear that the moving force in the erection of an obelisk on the Claremont site to commemorate the scientific achievements and social contribution of Sir John Herschel at the Cape was Charles Piazzi Smyth. Smyth had connections in Edinburgh able to procure the granite used for the structure. His family had an interest in archaeology and specifically in the obelisks of Egypt. Throughout his life, Smyth was interested in things Egyptian and made use of John Dixon, the engineer who had helped him measure the pyramids and who had designed the ill-fated vessel in which Cleopatra's Needle had been transported from Alexandria to London. Wilson (1878: 194), the financier of the transportation of Cleopatra's Needle to London, notes Piazzi Smyth's concern about damaging Egyptian antiquities:

'I quite concur with Professor Piazzi Smyth in denouncing the barbarism of breaking off pieces of, and carrying away, Egyptian antiques; but I think we might remove the prostrate obelisk hidden and buried in the sand, leaving, of course, the twin obelisk set up in its place, and always most interesting as a Cleopatra's needle.'

Both the Herschel obelisk and Cleopatra's Needle were commemorative in function and contained time capsules. ${ }^{46}$ It is also certain that the choice of an obelisk to commemorate Herschel's visit to the Cape was not accidental. No doubt this structure - the quintessential instrument of marking space and time - was used to indicate the spot at which great astronomical discoveries had been made, but as the erection of obelisks in London and New York show, such monuments also make strong cultural statements. They were inscribed with records of imperial conquest and the divine elevation of the ruler. It has been argued, wrongly in my view, that Herschel's expedition to the Cape was designed to justify British seizure of the Cape from the Dutch during the Napoleonic Wars and their subsequent occupation of the settlement. ${ }^{47}$ Nevertheless, the erection of an obelisk in Cape Town did more than

45 See, for example, Burgess (1862 - a lecture delivered in May 1858); Parker 1879; and Iversen 1968, Vol. 1. For the 'Imperialist Appropriations of Egyptian Obelisks', see Hassan 2003.

46 A brass plate with an inscription was hidden inside the Alexandrian obelisk and later many other objects were enclosed in it. These are listed in Budge 1926: 71.

47 Ruskin 2004. Against this view, must stand the undeniable fact that Herschel repeatedly refused funding from the British Government and paid all expenses from his own resources. 
merely celebrate scientific discoveries. It brought with it overtones of the cultural preoccupations and intellectual debates of the educated English visitors in the early nineteenth century.

\section{BIBLIOGRAPHY}

Barnard, K H 1954. Sir John Herschel and the S.A. Literary and Scientific Institution. Quarterly Bulletin of the South African Library 9: 10-11, 13.

Brück, H A and Brück, M T 1988. The peripatetic astronomer : the life of Charles Piazzi Smyth. Bristol: Hilger.

Burgess, R 1862. On the Egyptian Obelisks in Rome, and monoliths as ornaments of Great Cities. Read at the Royal Institute of British Architects, May 31st 1858. London.

Buttman, G 1970. The shadow of the telescope: a biography of John Herschel. New York: Charles Scribner.

Carrot, R G 1978. The Egyptian Revival: Its Sources, Monuments, and Meaning 1808-1858. Berkeley, Los Angeles, London: University of California Press.

Casey, C 1877. Philitis: being a condensed account of the recently discovered solution of the use and meaning of the Great Pyramid ... To which is added a review of Professor Piazzi Smyth's second edition of Our Inheritance in the Great Pyramid. Fourth edition, illustrated, revised and enlarged. Dublin: Carson Bros.

Curl, J S 1994. Egyptomania: The Egyptian Revival -- A Recurring Theme in the History of Taste. Manchester and New York: Manchester University Press.

Evans, H R 1895. The Great Pyramid and Napoleon I. A masonic study, containing a complete bibliography of pyramid literature. Washington: Hartman \& Cadick.

Evans, D S, Deeming, T J, Evans, B H and Goldfarb, S (eds) 1969 Herschel at the Cape. Diaries \& correspondence of Sir John Herschel, 1834-1838.: Cape Town: A. A. Balkema.

Ferguson, W T and Immelman, R F M 1961. Sir John Herschel and Education at the Cape 1834-1840. Cape Town: Oxford University Press.

Fernie, D 1976. ' . . . In the Country of the Hottentots': Maclear and Herschel in South Africa. In Fernie, D (ed.) The Whisper and the Vision: The Voyages of the Astronomers, 57-105. Toronto: Clarke, Irwin \& Company.

Gorringe, H H 1882. Egyptian Obelisks ... Illustrated, etc. New York: The Author.

Greaves, J 1646. Pyramidographia: or, a description of the pyramids in Aegypt. London.

Greaves, J 1706. The origine and antiquity of our English weights and measures discover'd. By their near agreement with such standards that are now found in one of the Egyptian pyramides ... By Mr. John Greaves, Astronomy Professor at Oxford, etc. London: G. Sawbridge, 2nd edition 1745 W. Payne.

Greaves, J 1732. A Discourse of the Roman Foot and Denarius: From whence, as from two principles, the measures and weights used by the ancients may be deduced. In A Collection of Voyages and Travels. London: John Walthoe. 
Habachi, L 1977. The Obelisks of Egypt: Skyscrapers of the Past. New York: Charles Scribner's Sons.

Harland-Jacobs, J L 2007. Builders of Empire: Freemasonry and British Imperialism 1717-1927. Chapel Hill: University of North Carolina Press.

Hassan, F A 2003. Imperialist Appropriations of Egyptian Obelisks. In Jeffreys, D (ed.) Views of Ancient Egypt since Napoleon Bonaparte: Imperialism, Colonialism and Modern Appropriations. London: UCL Press.

Herschel, J F W 1833. Schiller's Spaziergang translated into Latin verse. London: Barrett and Sons.

Herschel, J F W 1834. A Course of Reading in 1834. Pretoria (reprinted from South African Libraries 7.3-4 [1940] 1-16).

Herschel, J F W 1849. Outlines of astronomy. [S.l.]: Longman, Brown, Green, Longmans.

Herschel, J F W 1863. An Essay, entitled the Yard, the Pendulum, and the Metre, considered in reference to the choice of a standard of length. ... Written for the Leeds Astronomical Society, and read before that body ... by $P$. O'Callaghan, etc. London, Leeds: Leeds Astronomical Society.

Herschel, J F W 1866. The Iliad of Homer translated into English accentuated hexameters. London and Cambridge: Macmillan.

Humbert, J-M, Pantazzi, M and Ziegler, C 1994. Egyptomania: Egypt in Western Art 1730-1930. Ottawa: National Gallery of Canada.

Iversen, E 1968. Obelisks in exile. Copenhagen: G.E.C. Gad.

Jeffreys, D (ed.) 2003 Views of Ancient Egypt Since Napoleon Bonaparte: Imperialism, Colonialism and Modern Appropriation. Oxford: Oxbow Books.

McIntyre, D 1954. The Herschel Obelisk. Quarterly Bulletin of the South African Library 8.3-4: 87-92.

Moldenke, C E 1891. The New York Obelisk: Cleopatra's Needle with a Preliminary Sketch of the History, Erection, Uses, and Signification of Obelisks. New York: Anson D. F. Randolph and Co.

Musselman, E G 1998. Swords into Ploughshares: John Herschel's Progressive View of Astronomical and Imperial Governance. British Journal for the History of Science 31: 419-436.

Napoleon I, Emperor of the French, Jomard, E F, Lelorgne de Savigny, M J C and Fourier, J B J 1809. Description de l'Égypte : ou, Recueil des observations et des recherches qui ont été faites en Égypte pendant l'expédition de l'armée française. Paris: Impression impériale.

Parker, J H 1879. The twelve Egyptian Obelisks in Rome: their history explained. Oxford: James Parker and Co.

Pieper, M and Van Buren, A W 1937. Obeliskos. In Pauly-Wissowa (ed.) Realencyclopaedie der classischen Altertumswissenschaft, 1705-1714. Stuttgart: Alfred Druckenmueller. See also the relevant article in Christine F. Salazar (ed.), Brill's New Pauly: Encyclopaedia of the ancient world.

Ross, S (ed.) 2001 Isabella Herschel's Catalogue of the Herschel Library. Troy, New York: Sydney Ross. 
Rowbottom, W 1880. The Origin of Masonic Ritual and tradition as manifested by the geometrical design and symbolism of the Great Pyramid: ... a lecture, etc. (Appendix. Old Testament Chronology revised and corrected, etc.). Alfreton: Published by the Author.

Ruskin, S 2004. John Herschel's Cape Voyage: Private Science, Public Imagination and the Ambitions of Empire. Science, Technology and Culture, 1700-1945. Aldershot: Ashgate.

Saïd, E W 1978. Orientalism: Western Conceptions of the Orient. London: Penguin.

Serino, F 2003. Description de l'Egypte. Vercelli: Editoriale Johnson / White Star Publications.

Smyth, W H 1834. Descriptive catalogue of a cabinet of Roman Imperial large-brass medals. Bedford: James Webb.

Smyth, C P 1867. Life and Work at the great Pyramid during the months of January, February, March, and April, A.D. 1865; with a discussion of the facts ascertained ... With illustrations, etc 3 Vols. Edinburgh: Edmonston, Douglas.

Smyth, C P 1868. On the Antiquity of Intellectual Man, from a practical and astronomical point of view. Edinburgh: Edmonston and Douglas.

Smyth, C P 1870. A poor man's photography at the Great pyramid in the year 1865, compared with that of the Ordnance survey establishment, a discourse. London.

Smyth, C P 1874. The Great Pyramid and the Royal Society (London). London: W. Isbister.

Smyth, C P 1874. Our inheritance in the Great pyramid. London: Daldy, Isbister.

Smuts, F 1960. Classical Scholarship and the Teaching of Classics at Cape Town and Stellenbosch.

Taylor, J 1859. The great pyramid : Why was it built? And who built it? London: Longman. Second edition published by Longman in 1864.

Vyse, R W H H and Perring, J S 1840. Operations carried on at the Pyramids of Gizeh in 1837: with an account of a voyage into Upper Egypt, and an appendix (containing a survey by J. S. Perring ... of the Pyramids at Abou Roash, etc.). 3 vols. with plates. London.

Wallis Budge, E A 1926. Cleopatra's Needles and Other Egyptian Obelisks: A Series of Descriptions of all the important inscribed obelisks with hieroglyphic texts, translations, etc. London: The Religious Tract Society.

Warner, B 1978. The Herschel Obelisk. Quarterly Bulletin of the South African Library 32.3: 56-92.

Warner, B 1983. Charles Piazzi Smyth Astronomer-Artist: His Cape Years 18351845. Cape Town: A. A. Balkema.

Warner, B 1984. Maclear \& Herschel: Letters \& Diaries at the Cape of Good Hope 1834-1838. Cape Town: A. A. Balkema.

Weisse, J A 1880. The Obelisk and Freemasonry According to the Discoveries of Belzoni and Commander Gorringe also Egyptian Symbols Compared with those Discovered in American Mounds. New York: J. W. Bouton.

Wilson, E 1877. Cleopatra's Needle: With Brief Notes on Egypt and Egyptian Obelisks. London: Brain \& Co. 